\title{
15. STABLE ISOTOPES OF OXYGEN AND CARBON IN CARBONATES AND ORGANIC MATERIAL FROM PLEISTOCENE TO UPPER MIOCENE SEDIMENTS AT SITE 374 (DSDP LEG 42A)
}

\author{
P. Hahn-Weinheimer, F. Fabricius, J. Müller, and W. Sigl, Institut für Geologie und Mineralogie, Technische \\ Universität München
}

\begin{abstract}
Twenty-three samples of Site 374 (Ionian Sea) Miocene to Quaternary carbonates were analyzed to determine their stable oxygen and carbon isotopes and mineralogical contents. In addition, the isotopic ratios of organic carbon were determined in eight samples of sapropel.

Different depositional environments provided different mechanisms of carbonate formation and deposition as suggested by characteristic isotopic and mineralogical compositions. The extremely low $\delta \mathrm{C}^{13}$ values of organic carbon in sapropels may be attributed to fractionation processes which are not completely understood at present.
\end{abstract}

\section{INTRODUCTION}

The eastern Mediterranean Sea has experienced a number of distinct changes during Tertiary and Quaternary time. It dried up during the late Miocene and has experienced periods of stagnation (late Miocene to Quaternary); the latter is indicated by sapropelic intercalations in the sedimentary sequences. In this study we attempt to document the effect of these changes on the formation, deposition, and diagenesis of carbonates by analysis of stable oxygen and carbon isotopes together with petrographic determinations of the mineralogic content. The isotopic compositions of both calcite and dolomite have been determined from 23 Miocene, Pliocene, and Pleistocene samples from Site 374 (Ionian Sea). Analyses include those of "normal" pelagic, as well as sapropels and "sapropelic," sediments. (See Sigl et al., this volume.)

In addition, $\delta \mathrm{C}^{13}$ of the organic material of eight sapropelic layers and sapropels, of the same age as those above, was analyzed to provide some information about the origin and the in-situ alteration of the sapropels.

\section{METHODS}

Samples were dried and ground to a grain size $<100 \mu \mathrm{m} . \mathrm{NaCl}$ was removed by rinsing with $\mathrm{H}_{2} \mathrm{O}$ and drying.

The carbonates were decomposed by concentrated $\mathrm{H}_{3} \mathrm{PO}_{4}$ according to the methods of McCrea (1950). Calciumcarbonate- and dolomite- $\mathrm{CO}_{2}$ were separated by exposing them for varying periods of time to acid (Epstein et al., 1964).

For the determination of $\delta \mathrm{C}^{13}$ for organic carbon, carbonate was removed by $\mathrm{HCl} 1: 1$ at $100^{\circ} \mathrm{C}$ during decarbonization. The residues were carefully rinsed with $\mathrm{H}_{2} \mathrm{O}$, dried at $120^{\circ} \mathrm{C}$ and 1 Torr in a $\mathrm{CO}_{2}$-free atmosphere. The organic carbon was combusted in a tubular furnace at $100^{\circ} \mathrm{C}$ in a stream of purified oxygen.

Contaminating compounds such as $\mathrm{SO}_{2}$ and $\mathrm{H}_{2}$ were removed by heated silver wool and a cold trap $\left(-20^{\circ} \mathrm{C}\right)$ respectively. Behind this trap, the $\mathrm{CO}_{2}-\mathrm{O}_{2}$ mixture passed a trap cooled with liquid nitrogen, where $\mathrm{CO}_{2}$ was condensed while $\mathrm{O}_{2}$ was pumped off.

For the measurement of $\delta \mathrm{C}^{13}$ and $\delta \mathrm{O}^{18}$ values for $\mathrm{CO}_{2}$, a mass spectrometer (Varian Mat, M86), with a double inlet system and a double collector was used. For the $\mathrm{C}^{13} / \mathrm{C}^{12}$ and $\mathrm{O}^{18} / \mathrm{O}^{16}$ ratios the following mass ratios were determined: $45 / 44$ and $46 /(44+45)$. They were measured for sample and standard alternately. The measured values were corrected after Craig (1957). The kinetic fractionation factors in the phosphoric acid with different carbonates (Sharma and Clayton, 1965) were not considered. The working standards were $\mathrm{CO}_{2}$ Linde puriss. and a NBS-graphite No. 21 , which were calibrated with the $\mathrm{BaCO}_{3}$-standard Stockholm and the PDB standard (Chicago) for oxygen and carbon. The precision of the mass spectrometric measurements was $0.3 \%$.

The details of the mineralogical analyses are described in Müller (this volume), and those for the organic carbon determination are described in Sigl (this volume).

The results of the isotopic and mineralogic analyses are compiled in Table 1 and Figure 1. The isotopic ranges within sediments of each age group are summarized in Table 2 . The $\delta \mathrm{C}^{13}$ values of the organic matter from selected sapropels are given in Table 3 together with the contents of organic carbon. 
TABLE 1

Calcite and Dolomite Content and Their Oxygen and Carbon Isotopic Compositions of Selected Samples From Site 374

\begin{tabular}{|c|c|c|c|c|c|c|c|c|c|c|c|}
\hline \multirow[b]{2}{*}{ Age } & \multirow[b]{2}{*}{ Sample } & \multirow{2}{*}{\multicolumn{2}{|c|}{ Facies }} & & & \multirow[b]{2}{*}{$\begin{array}{l}\text { Mol\% } \\
\text { Ca/Mg } \\
\text { dolom. }\end{array}$} & \multirow[b]{2}{*}{ Mineralogical Content } & \multicolumn{2}{|c|}{ Calcite } & \multicolumn{2}{|c|}{ Dolomite } \\
\hline & & & & \multicolumn{2}{|c|}{$\begin{array}{c}\text { Calcite } \\
\text { Dolomite } \\
\text { (weight-\%) }\end{array}$} & & & \multicolumn{2}{|c|}{$\begin{array}{c}{ }^{\delta} 018{ }^{\delta} \mathrm{C} \\
\%_{0} \\
\text { vs. PDB }\end{array}$} & \multicolumn{2}{|c|}{$\begin{array}{c}{ }_{0}^{\delta}{ }^{18}{ }_{\%}{ }^{\delta} \mathrm{C}^{13} \\
\text { vs. PDB }\end{array}$} \\
\hline \multirow{7}{*}{ 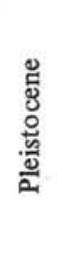 } & $374-2, \mathrm{CC} / \mathrm{N}$ & Normal (tur & & 14 & 12 & $50 / 50$ & $\mathrm{MgCa}, \mathrm{AR}, \mathrm{Q}, \mathrm{KF}, \mathrm{PL}, \mathrm{IL}$ & +1.55 & +0.99 & +1.62 & -1.63 \\
\hline & $374-2, \mathrm{CC} / \mathrm{S}$ & Sapropelic & & 37 & 1 & - & $\mathrm{Q}, \mathrm{KF}, \mathrm{PL}, \mathrm{GY}, \mathrm{PY}, \mathrm{IL}, \mathrm{CH}, \mathrm{KA}$ & -0.11 & -0.01 & - & - \\
\hline & $374-3, \mathrm{CC}$ & Sapropelic & & 19 & 4 & $50 / 50$ & $\mathrm{Q}, \mathrm{KF}, \mathrm{PL}, \mathrm{IL}, \mathrm{CH}, \mathrm{KA}$ & +0.37 & +0.14 & +1.04 & -1.27 \\
\hline & $374-4-2,57-58 \mathrm{~cm}$ & Sapropel & & 41 & - & - & $\mathrm{Q}, \mathrm{KF}, \mathrm{PL}, \mathrm{GY}, \mathrm{PY}, \mathrm{IL}, \mathrm{CH}, \mathrm{KA}$ & +0.48 & -0.56 & & - \\
\hline & $374-4-2,59.5-60.5 \mathrm{~cm}$ & Normal & & 30 & - & - & Q,KF,PL,GY,PY,IL,CH,KA & +0.83 & -0.39 & - & - \\
\hline & $374-4-3,2-4 \mathrm{~cm}$ & Normal & & 18 & 4 & $\begin{array}{l}50 / 50 \\
54 / 46\end{array}$ & $\mathrm{Q}, \mathrm{KF}, \mathrm{PL}, \mathrm{IL}, \mathrm{CH}, \mathrm{KA}$ & +1.24 & +0.32 & +1.66 & -1.59 \\
\hline & $374-4-4,75-76 \mathrm{~cm}$ & Normal & & 24 & 1 & - & $\mathrm{Q}, \mathrm{KF}, \mathrm{PL}, \mathrm{IL}, \mathrm{CH}, \mathrm{KA}$ & +1.28 & +1.03 & - & - \\
\hline \multirow[t]{2}{*}{ 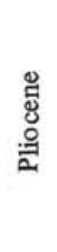 } & $\begin{array}{l}374-5-3,53-54 \mathrm{~cm} \\
374-6-1,4-5 \mathrm{~cm} \\
374-6-1,29-30 \mathrm{~cm} \\
374-6-3,12.5-13.3 \mathrm{~cm} \\
374-7-6,52-57 \mathrm{~cm} \\
374-8-1,115-116 \mathrm{~cm}\end{array}$ & $\begin{array}{l}\text { Normal } \\
\text { Normal } \\
\text { Normal } \\
\text { Normal } \\
\text { Normal } \\
\text { Normal }\end{array}$ & & $\begin{array}{l}44 \\
39 \\
41 \\
64 \\
48 \\
55\end{array}$ & $\begin{array}{r}\overline{12} \\
15 \\
\overline{6} \\
12\end{array}$ & $\begin{array}{c}- \\
54 / 46 \\
54 / 46 \\
- \\
54 / 46 \\
54 / 46\end{array}$ & $\begin{array}{l}\text { Q,KF,PL,GY,PY,IL } \\
\text { Q,KF,PL,IL } \\
\text { Q,KF,PL,IL } \\
\text { Q,KF,PL,IL } \\
\text { Q,KF,PL,IL } \\
\text { Q,KF,PL,IL }\end{array}$ & $\begin{array}{l}+0.71 \\
+1.87 \\
+1.07 \\
+1.09 \\
+1.45 \\
+2.33\end{array}$ & $\begin{array}{l}-0.26 \\
+0.28 \\
+0.31 \\
+0.81 \\
+0.63 \\
+1.41\end{array}$ & $\begin{array}{l}- \\
+4.61 \\
+4.85 \\
- \\
- \\
+4.56\end{array}$ & $\begin{array}{l}- \\
+1.08 \\
+1.63 \\
- \\
- \\
+1.67\end{array}$ \\
\hline & $374-8-2,24-26 \mathrm{~cm}$ & Normal & & 43 & 9 & $\begin{array}{l}50 / 50 \\
54 / 46\end{array}$ & $\mathrm{Q}, \mathrm{KF}, \mathrm{PL}, \mathrm{IL}, \mathrm{CH}, \mathrm{KA}$ & +2.09 & +0.91 & +3.40 & +1.50 \\
\hline 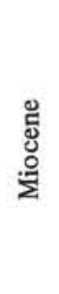 & $\begin{array}{l}374-11-2,112 \mathrm{~cm} \\
374-12-2,99-100 \mathrm{~cm} \\
374-14-1,100-102 \mathrm{~cm} \\
374-14-2,35-37 \mathrm{~cm} \\
374-15-1,69-70 \mathrm{~cm} \\
374-15-2,79-81 \mathrm{~cm} \\
374-16-1,72-75 \mathrm{~B} \mathrm{~cm} \\
374-17-1,80-81 \mathrm{~cm} \\
374-19-1,28-29 \mathrm{~cm}\end{array}$ & $\begin{array}{l}\text { Dolomitic } \\
\text { Normal } \\
\text { Normal } \\
\text { Sapropelic } \\
\text { Sapropelic } \\
\text { Normal } \\
\text { Sapropel } \\
\text { Sapropel } \\
\text { Normal }\end{array}$ & 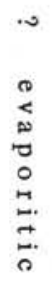 & $\begin{array}{c}- \\
- \\
- \\
- \\
- \\
\overline{-} \\
\text { not dete } \\
- \\
-\end{array}$ & $\begin{array}{c}79 \\
21 \\
19 \\
22 \\
25 \\
23 \\
\text { rmined } \\
37 \\
51\end{array}$ & $\begin{array}{l}55 / 45 \\
55 / 45 \\
55 / 45 \\
55 / 45 \\
55 / 45 \\
55 / 45 \\
-- \\
55 / 45 \\
55 / 45\end{array}$ & $\begin{array}{l}\text { Q,PL,IL,CH,KA } \\
\text { Q,PL,GY } \\
\text { Q,KF,PL,IL,CH,KA,L } \\
\text { Q,KF,PL,IL,CH,KA,L } \\
\text { Q,KF,PL,IL,CH,KA,L } \\
\text { Q,KF,PL,IY?,IL,CH,KA } \\
\text { - } \\
\text { Q,GY,AN,HA,IL } \\
\text { MAG,Q,GY,AN,IL,HA }\end{array}$ & $\begin{array}{l}- \\
- \\
- \\
- \\
- \\
- \\
-\end{array}$ & $\begin{array}{l}- \\
- \\
- \\
- \\
- \\
- \\
- \\
-\end{array}$ & $\begin{array}{l}+5.60 \\
+4.67 \\
+4.76 \\
+5.13 \\
+4.90 \\
+3.12 \\
+4.64 \\
+5.45 \\
+5.76\end{array}$ & $\begin{array}{l}+1.18 \\
-1.02 \\
-1.75 \\
-1.39 \\
-1.77 \\
-2.45 \\
-6.69 \\
-6.93 \\
-4.02\end{array}$ \\
\hline
\end{tabular}

Note: $\mathrm{MgCa}=\mathrm{Mg}$-Calcite, $\mathrm{AR}=$ Aragonite $, \mathrm{Q}=\mathrm{Quartz}, \mathrm{KF}=$ Kalifeldspar, $\mathrm{PL}=$ Plagioclase $, \mathrm{IL}=\mathrm{Illite}, \mathrm{CH}=\mathrm{Chlorite}, \mathrm{KA}=\mathrm{Kaolinite}$, $\mathrm{PY}=$ Pyrite, $\mathrm{GY}=$ Gypsum, $\mathrm{L}=$ Lüneburgite, $\mathrm{HA}=$ Halite, $\mathrm{MAG}=$ Magnesite, $\mathrm{AN}=$ Anhydrite, $\mathrm{N}=\quad \mathrm{S}=$

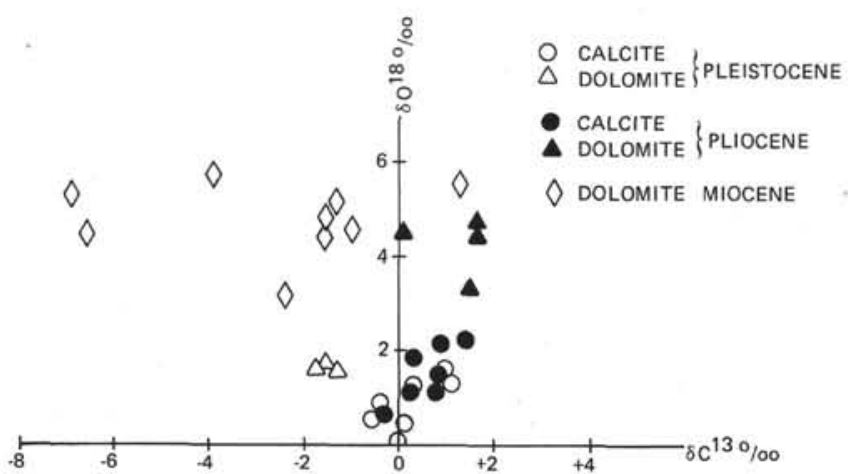

Figure 1. Plot of $\delta C^{13}$ versus $\delta O^{18}$ for selected samples of Site 374, Leg $42 A$.

TABLE 2

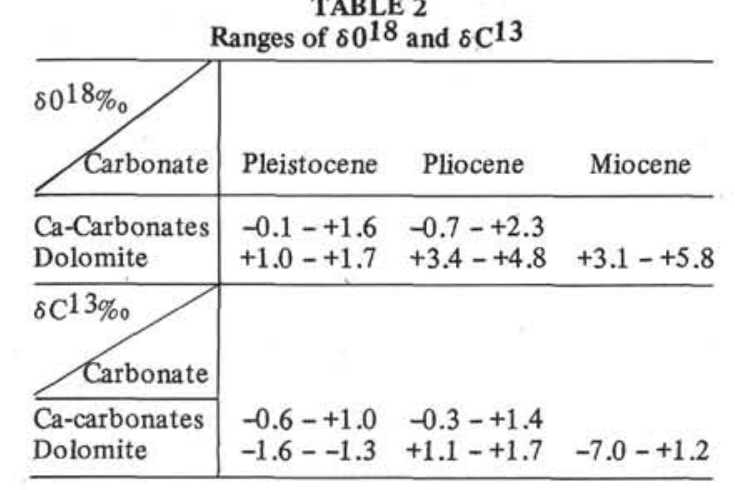

TABLE 3

Carbon-Isotope Ratios of Organic Material

\begin{tabular}{cllcc}
\hline Age & \multicolumn{1}{c}{ Sample } & \multicolumn{1}{c}{ Facies } & $\begin{array}{c}\text { Organic } \\
\text { Carbon } \\
\text { (weight \%) }\end{array}$ & $\begin{array}{c}\delta \mathrm{Cl}^{13} \\
(\%)\end{array}$ \\
vs. PDB
\end{tabular}

\section{RESULTS}

\section{Miocene Dolomite}

Dolomite is the major carbonate phase present within the Miocene evaporitic sequence. Its abundance is usually between $20 \%-25 \%$, but is $31 \%$ in one case. Magnesite occurs only in a few samples and its occurrence is not discussed in this paper. The dolomites which are either associated with Ca-sulfates (gypsum and anhydrite; Cores 16 to 22) as well as those from the overlying marls (Cores 12 to 15 ) contain an excess of $\mathrm{Ca}$ of 5 mole-\%. The range of $\delta \mathrm{O}^{18}$ of the Messinian dolomites is +3.12 to $+5.76 \%$, but $\delta \mathrm{C}^{13}$ appears to be separated into two groups. These groups, from the 
dolomitic marls (Cores 12 to 15 ), range between -1.02 and $-2.45 \%$. Those dolomites which are associated with gypsum or anhydrite showed $\delta \mathrm{C}^{13}$ values from -4.02 to $-6.69 \%$. These ranges are smaller than but are nevertheless in agreement with, those reported by Lloyd and Hsü (1973) and by Fontes et al. (1973) for late Miocene dolomites.

SEM investigations of the dolomites associated with Ca-sulfates showed subhedral crystals smaller than $5 \mu \mathrm{m}$ embedded in a whisker-like clayey matrix (Figure 2 ). In contrast, the overlying marls contain dolomitic euhedral crystals of about $10 \mu \mathrm{m}$ in size. Also crystals have inclusions and overgrowths here. (Figure 3).

It is generally accepted that the late Miocene (Messinian) evaporites were formed in a shallow-water environment (Kuehn and Hsü, 1974). Hypersalinity in precipitation of Ca-sulfates with a subsequent increase in the $\mathrm{Mg} / \mathrm{Ca}$-ratio were favorable for the earlydiagenetic formation of $\mathrm{Mg}$-carbonates. We do not know whether the Ca-dolomites, present within the Messinian evaporites of Site 374, represent "primary" phases of carbonate precipitation or were a result of transformation of other carbonates (such as Mg-calcite). If they are in the early stages of diagenesis and thus have their primary isotopic composition, then all dolomites analyzed from this section must have formed under (more or less) comparable evaporitic conditions.

Note that the dolomites from the Messinian evaporites of the Red Sea differ from those of the Mediterranean Sea in both isotopic and mineralogic composition. Red Sea dolomites have been found to be stoichiometric and are mostly depleted in $\delta \mathrm{O}^{18}$ (Supko et al., 1974).

\section{Pliocene Carbonates}

The upper Miocene dolomitic marls are overlain by an indurated (Miocene to Pliocene) dolostone ( $~ 80 \%$ dolomite; Core 11). Numerous "holes," relics from dissolution of calcitic planktonic foraminifer tests (Figure 4) and recrystallized coccolithophorids (Bernoulli et al., this volume) indicate that they were deposited in open marine conditions and have undergone extensive diagenetic alteration. Dolomitization probably was caused by upward-migrating brines which had been enriched in $\mathrm{Mg}$ by dissolution of late-stage evaporitic minerals. The mineralogic composition $\left(\mathrm{Ca}_{55}, \mathrm{Mg}_{45}\right)$ of the dolomite is identical with that of the Miocene dolomites and the dolomite has an unusual platey habit (Figure 5) which is discussed in detail by Bernoulli and Melieres (this volume). Its isotopic composition, however, being enriched in $\mathrm{C}^{13}\left(\delta \mathrm{C}^{13}=\right.$ $+1.18 \%$ ) is different from the Miocene dolomites which in our samples have negative $\delta \mathrm{C}^{13}$ values.

This dolomitic layer is overlain by marl containing calcite $(40 \%-65 \%)$ and dolomite $(0 \%-15 \%)$ which represent "normal" hemipelagic sedimentation. The calcite is derived mainly from planktonic foraminifers and coccolithophorids, and the resulting isotopic composition of the calcites has $\delta \mathrm{O}^{18}$ and $\delta \mathrm{C}^{13}$ ranges which are normal for pelagic oozes.

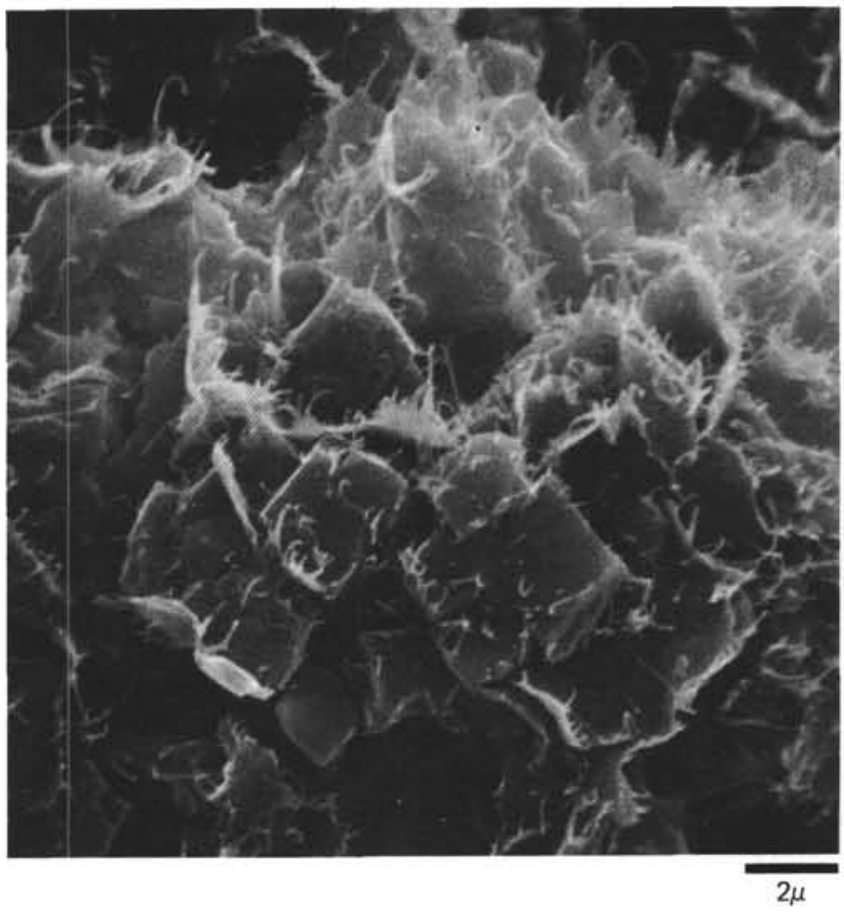

Figure 2. Site 374, Core 19, Section 1, 28-29 cm; Messinian. SE micrograph of a fractured dolomitric marl. Subhedral dolomite crystals are embedded in thin films of clay minerals, the edges of which show typically fibrous to "whisker-like" appearance.

The dolomites analyzed from the Pliocene compared to the Miocene sequence are characterized by a less pronounced $\mathrm{Ca}$-excess $\left(\mathrm{Ca}_{54}, \mathrm{Mg}_{46}\right)$. Their $\delta \mathrm{O}^{18}$ range between $+3.4 \%$ and $4.85 \%$ and their $\delta \mathrm{C}^{13}$ from $+1.08 \%$ o to $1.67 \%$.

Interstitial waters within the Pliocene sequence are enriched in both $\mathrm{Ca}$ and $\mathrm{Mg}$ (average: $\mathrm{x} 40$ and $\mathrm{x} 21$, respectively) compared to seawater. Their $\mathrm{Mg}$ : $\mathrm{Ca}$ ratios range between $2.66 \%$ and $4.35 \%$ (see Site 374 Report, this volume) and might, therefore, have led to a late diagenetic formation of dolomite.

Although we favor the view of authigenic formation of dolomite within the Pliocene carbonates we cannot rule out a detrital origin for at least some part of it.

\section{Pleistocene Carbonates}

The samples analyzed from the Pleistocene represent "normal" marine and anoxic stagnant conditions during deposition and also contain some turbiditic material.

The dominant carbonate phase is calcite $(15 \%-40 \%)$. Dolomite is rare (maximum $12 \%$ ) or absent. The major contributors of calcite are planktonic foraminifers and coccoliths. The latter group shows distinct differences in preservation; the coccoliths from the sapropels show little or no corrosion or overgrowth (Figure 6, compare Sigl et al., this volume) but those from the hemipelagic sediments are partially dissolved and (or) recrystallized as indicated by diffuse boundaries and overgrowth (Figure 7). Also, differences in isotopic composition of calcites between the two envi- 


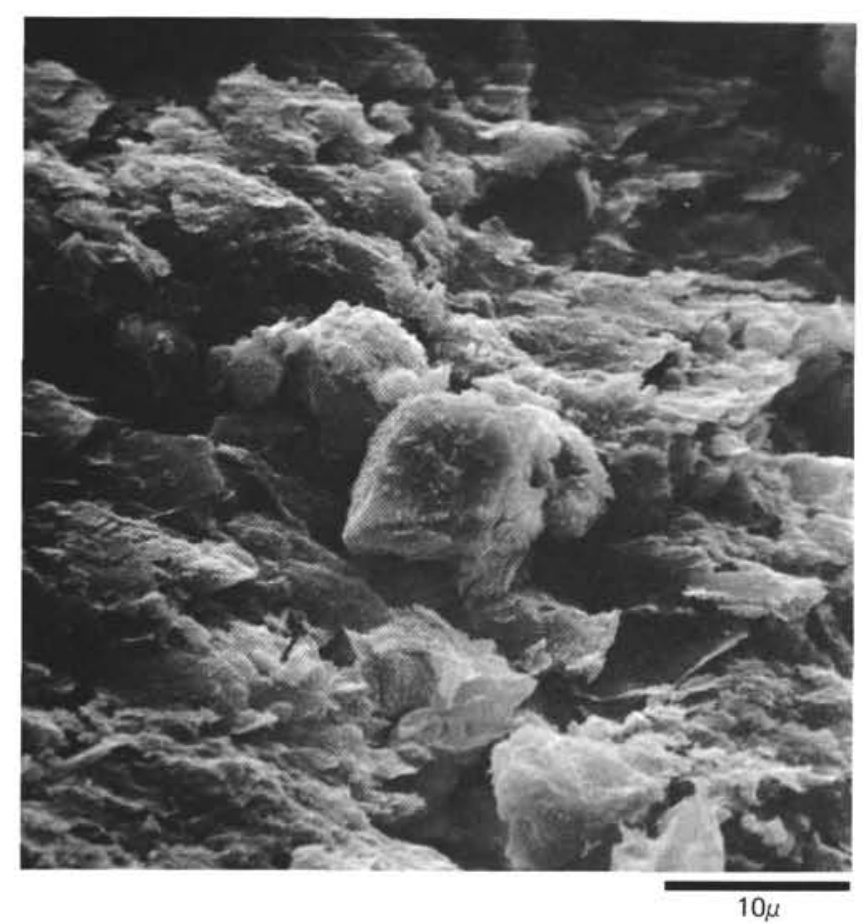

Figure 3. Site 374, Core 12, Section 2, 97-101 cm; Messinian dolomitic marl. Dolomite rhombohedron (center) embedded in an argillacious carbonate matrix.

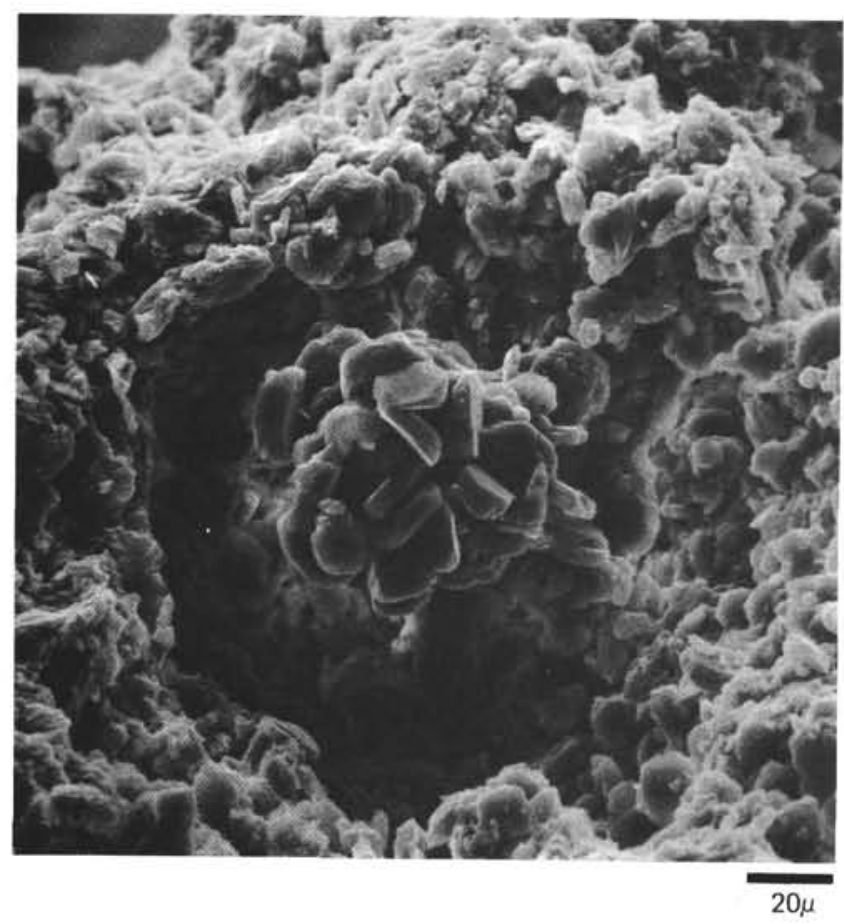

Figure 4. Site 374, Core 11, Section 2, 147-149 cm; near Miocene/Pliocene. Cross-fracture of a dolostone. The spherical cavern is a remnant of a dissolved planktonic foraminifer test. The cluster of almost euhedral dolocrystals forms a structure in the center of the foraminifer test which indicates that the dolomitization occurred before dissolution of the foraminifer test. The habit of these crystals shows excellent development of the (1000) planes.

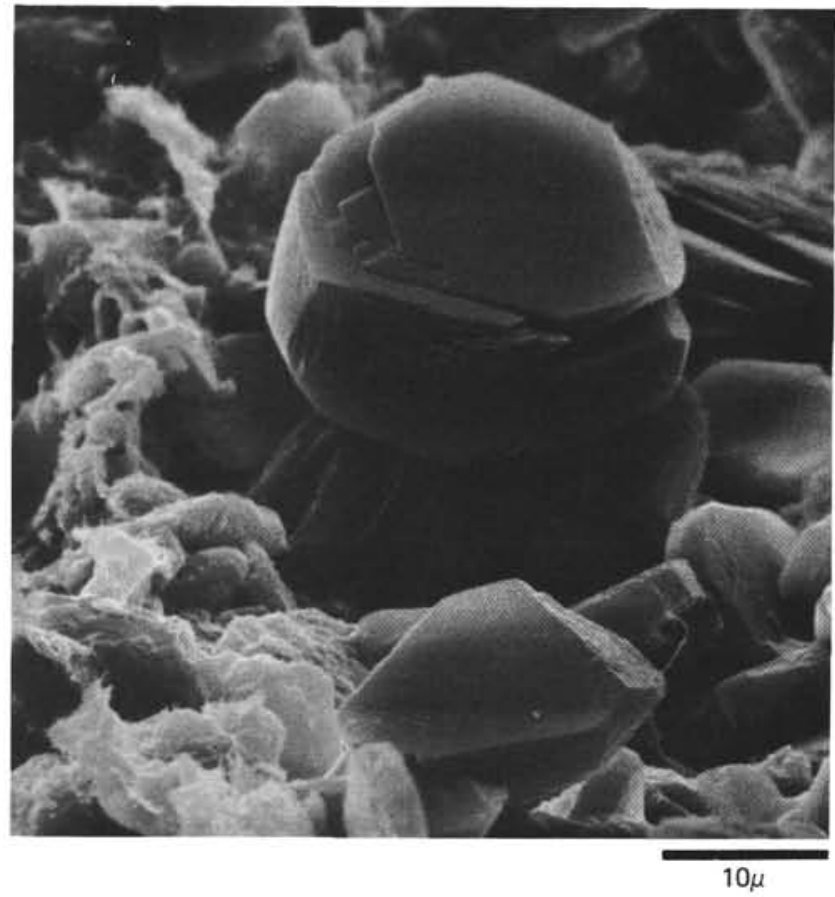

Figure 5. Site 374, Core 11, Section 2, 120-121 cm; near Miocene/Pliocene boundary. Abnormal habit of dolomite crystals.

ronments appear to exist. Calcites from the sapropels have lower $\delta \mathrm{O}^{18}$ and $\delta \mathrm{C}^{13}$ values than those from normal sediments. These differences might be a result of differences in salinity and/or temperature, different planktonic associations or diagenetic alterations.

The sample from the turbidite (Sample 2, CC) contains, in addition to calcite and dolomite, aragonite and $\mathrm{Mg}$-calcite derived from shallow water material (Müller et al., this volume). The isotopic composition therefore represents an average of the different carbonate phases.

The dolomites from the three depositional environments of the Pleistocene section have rather similar mineral contents. They are, for the most part, stoichiometric and differ in their isotopic composition from those of the Pliocene and Miocene. Their $\delta \mathrm{O}^{18}$ values range from $+1.04 \%$ o to $+1.66 \%$ : those of $\delta \mathrm{C}^{13}$ range from $-1.27 \% \circ$; to $-1.63 \%$. As their presence within the turbidite sample indicates, we must look for the source of these more or less euhedral $20 \mu \mathrm{m}$-sized dolomitic crystals (Figure 8 ) in the circum-Ionian limestones.

\section{Organic Matter}

The isotopic ratios of organic carbon in sapropelic sediments and sapropels of Site 374 are extremely low and vary between $-29.58 \%$ and $-56.75 \%$. Similar low values are known from biogenic compounds such as $\mathrm{CH}_{4}$ (Sackett and Menendez, 1971), which can be produced during sulfate reduction in anaerobic environments (Barnes and Goldberg, 1976). 


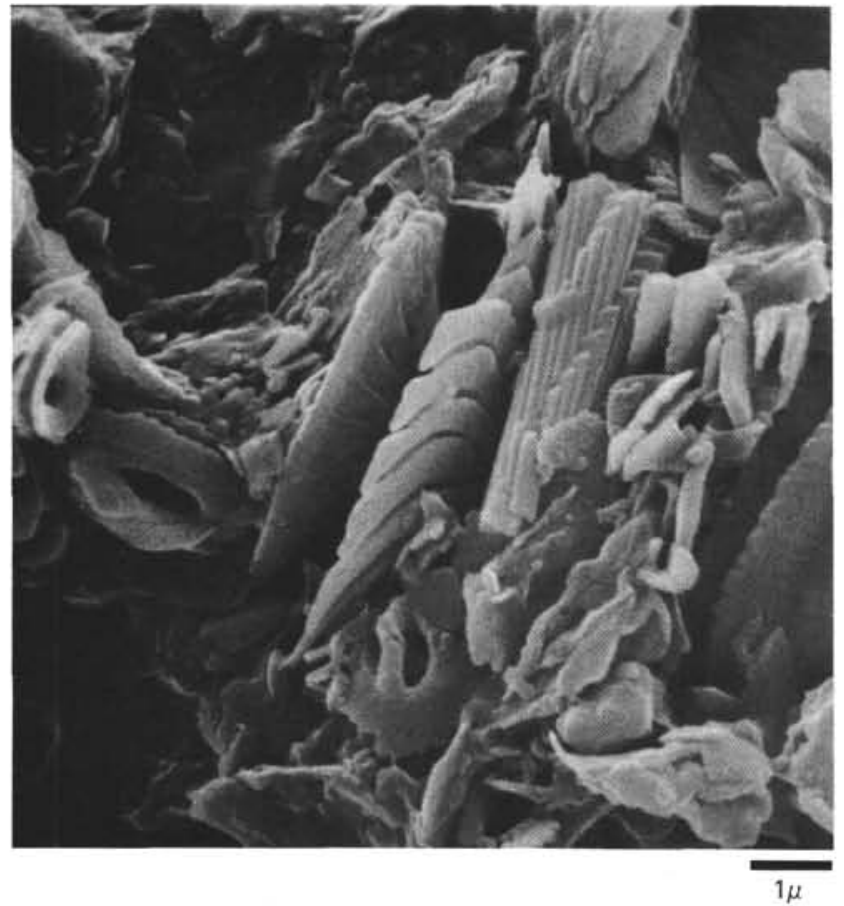

Figure 6. Site 374, Core 4, Section 2, $57-57.5 \mathrm{~cm}$; Quaternary. Sapropelic layer (2.5\% organic carbon); composition predominantly of calcitic fragments of coccoliths (Leptoporus sp. Rhabsosphaera sp., and others) and argillacious matter.

No trends related to the age, organic carbon content, or depositional environment of the sediments are detected from the few data given on Table 3. Provided that no unknown analytical error has altered these values, they must be considered as a result of complex diagenetic processes in the stagnant environment. A possible process might be the decarboxylation of the protein fraction which is a common reaction in organic material undergoing bacterial decomposition and which produces a relative enrichment in $\mathrm{C}^{12}$ in the residual organic carbon (Degens et al., 1968). On the other hand, the low values of our samples could hardly have been achieved by this single process. It is more likely that a series of transformations with several fractionating steps has taken place.

The origin of the organic material in Mediterranean sapropels is still an object of discussion. $\mathrm{C} / \mathrm{N}$ ratios and distribution of n-alkanes of the sapropels suggest a greater contribution of terrigenous organic material to the supply of organic matter during sapropel formation (Sigl et al., this volume). With respect to the isotopic ratios, the value of Sample 6-3, 65.8-66.7 $\mathrm{cm}$ with $\delta \mathrm{C}^{13}$ of $-29.58 \%$ fits into the isotopic range of land plants given by Sackett (1964).

\section{ACKNOWLEDGMENTS}

We thank the Bundesminister für Forschung und Technologie and the Deutsche Forschungsgemeinschaft for their financial support. We are grateful to M. Ullrich and W. Graf for the performance of the mass spectrometric determinations.

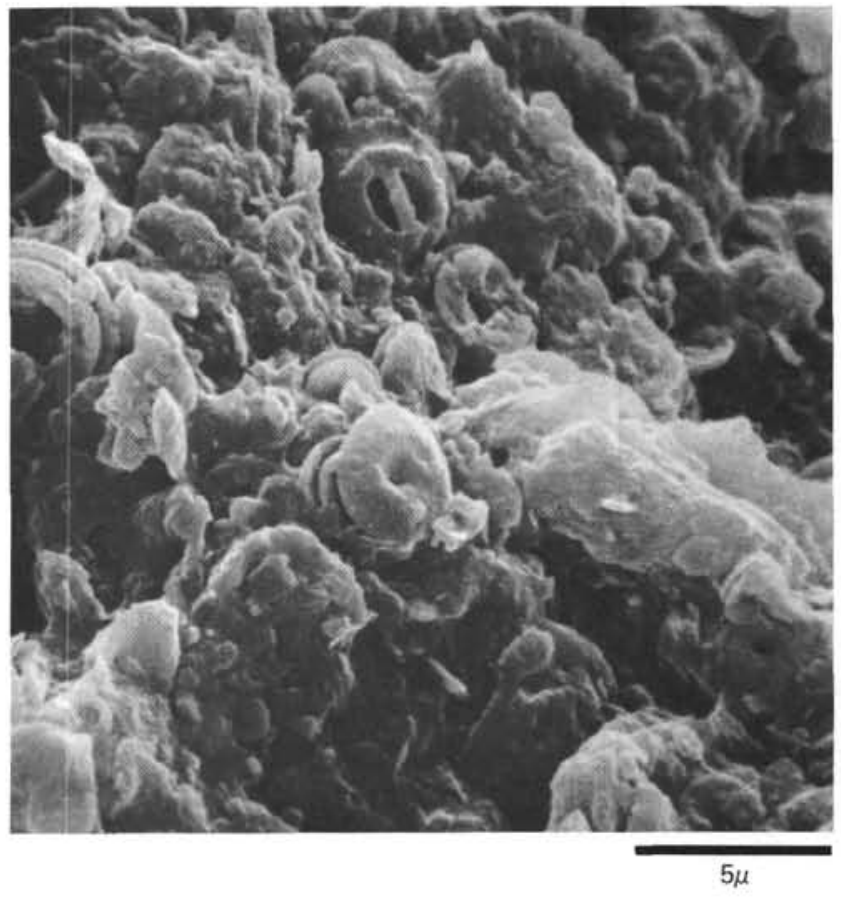

Figure 7. Site 374, Core 4, Section 4, 75-76 cm; Quaternary. Normal hemipelagic sediment (total carbonate 25\%; calcite 24\%; dolomite 1\%) composed mainly of coccoliths (calcite) and clay minerals, the latter give a smooth appearance to the surface of the fractured sample.

\section{REFERENCES}

Barnes, R. O. and Goldberg, E. D., 1976. Methane production and consumption in anoxic marine sediments: J. Geol., v. 4, p. 297.

Clayton, R. N. and Epstein, S., 1958. The relationship between $\mathrm{O}^{18} / \mathrm{O}^{16}$ ratios in coexisting quartz, carbonate and iron oxides from various geological deposits: J. Geol., v. 66, p. 352 .

Craig, H., 1957. Isotopic standards for carbon and oxygen and correction factors for mass spectrometer analysis of carbon dioxide: Geochim. Cosmochim. Acta, v. 12, p. 133.

Degens, E. T., Behrendt, M., Gotthardt, B., and Reppmann, E., 1968. Metabolic fractionation of carbon isotopes in marine plankton II. Data on samples collected off the coasts of Peru and Ecuador: Deep-Sea Res., v. 15, p. 11.

Epstein, S., Graf, D. L., and Degens, E. T., 1964. Oxygen isotope studies on the origin of dolomites. In Craig, H., and Müller, S. L., and Wasseiburg, G. T. (Eds.), Isotopic and cosmic chemistry, ded. to H. D. Urey's 70th birthday: Amsterdam (North Holland).

Fontes, J.-Ch., Letolle, R., and Nestroff, W. D., 1973. Oxygen, carbon, sulfur and hydrogen stable isotopes in carbonate and sulfate mineral phases of neogene evaporites, sediments, and in interstitial waters. In Ryan, W. B. F., Hsü, K., et al., Initial Reports of the Deep Sea Drilling Project, Volume 13: Washington (U.S. Government Printing Office), p. 788.

Kuehn, S. R. and Hsü, K. J., 1974. Bromine content of Mediterranean halite: Geology, v. 2, p. 213.

Lloyd, R. M. and Hsü, K. J., 1973. Preliminary isotopic investigations of samples from Deep Sea Drilling in the Mediterranean Sea. In Ryan, W.B.F., Hsü, K. et al., Initial 


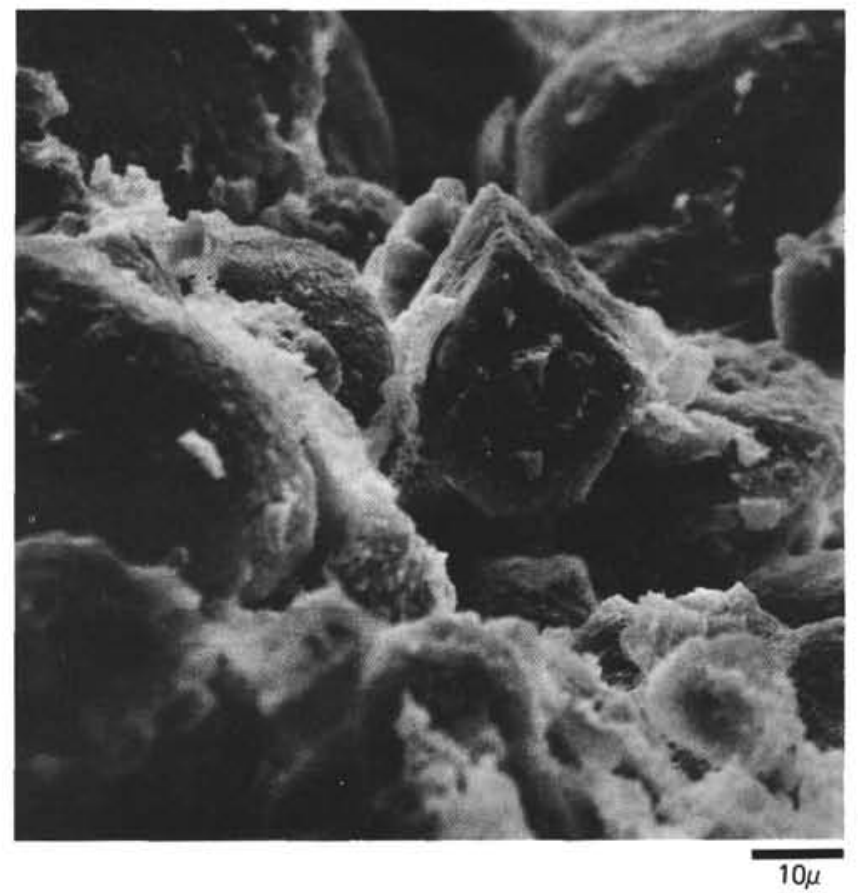

Figure 8. Site 374, Core 2, CC, Quaternary. Fractured sample of a coarse turbiditic sediment which contains many rounded sedimentary and biogenic clasts and some dolomite rhombohedrons.

Reports of the Deep Sea Drilling Project, Volume 13: Washington (U.S. Government Printing Office), p. 783.

McCrea, J. M., 1950. On the isotopic chemistry of carbonates and a paleo-temperature scale: J. Chem. Phys., v. 18, p. 849.

Sackett, W. M., 1964. The depositional history and isotopic organic carbon composition of marine sediments: Marine Geol., v. 2, p. 173.

Sackett, W. M. and Menedez, R., 1971. Carbon isotope study of the hydrocarbons and kerogen in the Aquitaine Basin,
Southwest France: Adv. in Org. Geochem. New York (Pergamon Press), p. 523-533.

Sharma, T. and Clayton, R. N., 1965. Measurement of $0^{18}$, $0^{16}$ ratios of total oxygen of carbonates: Geochim. Cosmochim. Acta, v. 29, p. 1347.

Supko, P. R., Stoffers, P. and Coplen, T. B., 1974. Petrography and geochemistry of Red Sea dolomite. In Whitmarsh, R. B., Ross, D. A., et al., Initial Reports of the Deep Sea Drilling Project, Volume 13: Washington (U.S. Government Printing Office), p. 867-868. 